\title{
Transnational Higher Education in Lithuania Birute Mockiene
}

Birute Mockiene is the executive director of the Lithuanian Center for Quality Assessment in Higher Education, Head of the Lithuanian ENIC/ NARIC, and Assistant Professor of the Vilnius Pedagogical University. She is curently a Humphry Fellow at Pennsylvania State University. Email: <bxm903@psu.edu>.

$\mathrm{N}$ ew categories of providers are entering the Lithuanian higher education system, which consists of 26 institutions. The system is binary, encompassing 19 universities and 7 nonuniversity institutions, 19 state and 7 private. This article looks at types of transnational education in Lithuania and identifies some problems with recognition of credentials.

The 1991 Lithuanian law on research and higher education allowed for two types of foreign initiatives: international institutions and joint establishments. The 2000 law on higher education included a provision allowing courses taught in foreign languages when the content of studies is related to another language, when a foreign professor or expert is invited to deliver a course in a foreign language, and when courses are delivered by Lithuanian higher education institutions in the framework of academic mobility agreements.

Three main features characterize the changing landscape of transnational higher education in Lithuania: diversification, demand, and market-driven supply and quality assurance. The result has been innovation and growth, as well as new problems for policymakers, stakeholders, and clients.

Diversification of ownership of institutions created more competition between providers, who face new demands for quality and innovation in the system. Through private initiatives endowments are generated and investments are encouraged. Students have a wider choice of programs.

In the decade since Lithuania's independence, the demand for higher education has not been satisfied in terms of the availability of study places or the relevance of content and structure. Almost half the youth cohort has remained outside the higher education system because of limited capacity that restricted access. A radically changing society and economy required new knowledge, skills, and competence of graduates. Although higher education institutions speeded up changes in curricula, there were many gaps in provision of programs needed for the new market economy. The speed of changes was also inadequate to meet the growing needs of the globalization of the Lithuanian economy.

Lithuania has a long tradition of excellence and rigor in its educational system. Quality has been a major issue when considering new initiatives and changes of the system. First, the concern for quality and excellence was always linked to the protection of the rights of customers, above all students. Second, a strong emphasis on quality hampered the flexibility of the system. Lessons learned from other Central and Eastern European countries, where a mushrooming of private and foreign education resu;ted in many problems, made Lithuanian policymakers and the academic community more cautions about the liberalization of the education system. Finally, conservative forces in academia used the issue of quality to preserve their monopoly over state institutions. While neighbors in Estonia, Latvia, and Poland were listing new private and transnational institutions, Lithuania was lagging behind in this field and was often called "too socialist." The situation did not change until 1999.

Although the terminology of transnational education is not present in higher education's legal provisions, new laws created a framework for a more liberal, flexible, and entrepreneurial academic culture in Lithuania. Some examples will highlight the benefits and drawbacks of the emerging transnational higher education sector in Lithuania.

\section{Transnational education is not synony- mous with international education.}

Transnational education is not synonymous with international education. For the purposes of this article, we define transnational education as the kind of education that goes beyond national borders. The UNESCO/Council of Europe Working Party, in collaboration with the European National Centers for Academic Recognition and Mobility (ENICs), identified the main types of transnational education: franchises, branch-campuses, twinning degrees, international institutions, large corporations, offshore institutions, distance, and virtual universities (UNESCO/Council of Europe, Code of Good Practice in the Provision of Transnational Education, 2000).

Franchising is defined as the process whereby a higher education institution from a certain country authorizes another institution or organization, from the same or another country, to provide its educational services. While it is a popular form of transnational education 
in many countries, only a few attempts have been made to launch franchised programs or courses in Lithuania.

The Open University of the United Kingdom delivers management courses in Vilnius via LINK, which is a semidistance education establishment based in Russia and recognized by the Russian authorities. The Open University remains the degree or certificate granting institution. The Department of Science and Higher Education under the Ministry of Education and Science of the Republic of Lithuania held discussions with the management program providers in Vilnius and encouraged them to apply for legal status. The process has been going on since 1999 without result. Students are taking a risk when enrolling in this illegal program. Although students appreciate the quality of the management program, their certificates cannot be recognized in the country since neither the Open University nor the Open University/LINK program has any legal status in Lithuania.

\section{Branch campuses in higher education have a relatively long tradition.}

Branch campuses in higher education have a relatively long tradition. A "mother" higher education institution from one country establishes a branch campus in another country in order to offer its own educational programs and qualifications. This model could be applied in the case of the Open University since the British institution is seeking to secure the right to award degrees and qualifications.

A slightly different initiative was taken by the Norwegian School of Management, which in 1999 established the first private institution in Lithuania-an International School of Management - in the second-largest city Kaunas and a small branch in the capital Vilnius. This institution provides high-quality programs on both undergraduate and graduate levels and offers a large number of executive training courses and other training programs to the business community of Lithuania. It has the right to award degrees.

A number of attempts have been made by the Baltic Russian University, which operates and is accredited in Latvia, and by the Russian State Industrial University, which is recognized in Moscow, to establish branch campuses in Lithuania. These initiatives have been discussed within the Department of Science and Higher Education. The founders will need to meet rigorous quality standards to obtain legal status.

Twinning degrees refer to those interinstitutional arrangements whereby two or more institutions agree to set up a joint study program with a credit transfer arrange- ment. All Lithuanian higher education institutions are implementing a credit transfer system. Most of them are partnering with European institutions within the SOCRATES/ERASMUS program, which promotes the European Credit Transfer System (ECTS). Gediminas'Technical University is developing partnerships with American universities and offers twinning degrees in business administration and management.

International institutions offer "international" qualifications that are not part of a specific national educational system. While there is no international higher education institution in Lithuania, an International Baccalaureat School has been established. It is considered a part of the Lithuanian secondary education system.

Lithuania Christian College in Klaipeda, established jointly by Canadian and Lithuanian charitable organizations, is a private nonprofit university dedicated to a liberal arts education and a Christian worldview, with an international campus community and international governing board. It might be considered an international institution. It has the right to award degrees in business administration and the English language.

Off-shore establishments are autonomous institutions that belong to no one particular national educational system and may not even have a campus in the country (or system) of its origin. In Lithuania, the Polish University initiative has been undertaken by the Polish Cultural Society and supported by some Polish academic interest groups. There is no Polish University in Poland. Fragmented attempts have been made since 1993 to establish an off-shore institution in Vilnius. Currently, the so-called Polish University delivers preparatory courses to students wanting to enter higher education institutions. These courses are not formally recognized as higher education programs, and thus transcripts from Polish University are not recognized in Lithuania.

Distance education provided by foreign higher education institutions is attracting more and more Lithuanian students. Since Internet access has expanded rapidly, the only obstacle to enrolling in on-line courses is the issue of their affordability. The issue of recognition is dealt with by the relevant information centers, which provide updated and reliable information on recognized distance education courses abroad.

\section{Distance education provided by foreign higher education institutions is attract- ing more and more Lithuanian students.}

The Lithuanian Center for Quality Assessment in Higher Education, serving as the Lithuanian ENIC/NARIC, in 
cooperation with the American Embassy, the British Council, and other institutions, provides information on the academic recognition of foreign degrees, including those provided on-line.

Chantal Kaufman, Head of the Belgian (French Community) ENIC, reported that credential evaluators almost always granted recognition to program articulations; sometimes granted recognition to franchised arrangements, branch campuses, off-shore institutions, and distance education; and almost never granted recognition to nonofficial corporate education or virtual universities.
Transnational education in Lithuania has created new opportunities for students as well as a diversified higher education system. These emerging transnational initiatives have been scrutinized in terms of quality assurance. The "Code of Good Practice in the Provision of Transnational Education," prepared under the auspices of the Council of Europe and UNESCO, proposed basic principles that have helped Lithuanian authorities, credential evaluators, and the academic community to make policy decisions on transnational education establishments and to protect students from fraudulent degrees and qualifications.

\section{China's Entry into the WTO and Higher Education}

\section{Yang Rui}

Yang Rui is a lecturer in the Faculty of Education, University of Western Australia, Nedlands, WA 6009, Australia. E-mail: $<$ ryang@ecel.uwa.edu.au>.

$\mathrm{N}$ early all agreements are in place for China to join the WTO after 15 years of trying. While the WTO as it currently stands does not have much to do with education, China's entry will require it to expand its policy of opening up to the outside world, which will have important implications for higher education. Currently, tens of thousands of Chinese parents send their children abroad to be educated, foreign institutions are scrambling for booths in China, and Chinese students are increasingly enrolling in programs offered by foreign institutions within China through distance education, twinning programs, and satellite campuses. Such trends will only be strengthened after the entry. Are these in the best interests of China? It is the purpose of this article to look at the Chinese response to see if the country is well prepared for the possible impacts of entry into the WTO on higher education.

\section{Education Specialists}

It is interesting to note how Chinese education specialists react to the prospect of entry into the WTO. Strangely enough, studies on possible impacts on China's education system have been lacking. Evidence shows that Chinese cademics in education are largely optimistic. Their reasoning is based on two factors: the knowledge economy and the global network. The knowledge industry is seen as a bridge linking education and the economy, increasingly blurring their borders. Knowledge and education, particularly higher education, function as both producer and transmitter and are, therefore, motors for economic growth. Knowledge innovations - the results of education — become the capital to promote economic development, which leads to further educational development.

\section{Many Chinese education researchers hold that entry into the WTO will pro- vide China with a number of education- related opportunities.}

Many Chinese education researchers hold that entry into the WTO will provide China with a number of education-related opportunities. The first lies in the distribution of new knowledge, in which intellectuals will play a major, pioneering role in the newborn Chinese knowledge economy. The second involves the application of that new knowledge. Entry into the WTO will further strengthen China's international educational exchange and help knowledge products expand in the global market. Third, with the production of new knowledge, a more equal environment for Chinese individuals and society can develop, with less of the traditional concentration on social status, gender, nationality, skin color, and age.

Chinese education specialists appear to be quite relaxed regarding WTO entry. In 2000, the authoritative Xinbua Wenzbai reprinted an article by Bao Guoqing, in which the author concludes that China's entry into the WTO and the free trade that ensues will help to establish a cultural and spiritual atmosphere that will foster freedom and will pave the way for individual personal development. According to Bao, the entry will inject the Olympic spirit 